\title{
A!
}

This is an electronic reprint of the original article.

This reprint may differ from the original in pagination and typographic detail.

Artto, Karlos; Kujala, Jaakko; Dietrich, Perttu; Martinsuo, Miia

\section{What is project strategy?}

Published in:

International Journal of Project Management

DOI:

10.1016/j.ijproman.2007.07.006

Published: 01/01/2008

Document Version

Peer reviewed version

Please cite the original version:

Artto, K., Kujala, J., Dietrich, P., \& Martinsuo, M. (2008). What is project strategy? International Journal of Project Management, 26(1), 4-12. https://doi.org/10.1016/j.ijproman.2007.07.006

This material is protected by copyright and other intellectual property rights, and duplication or sale of all or part of any of the repository collections is not permitted, except that material may be duplicated by you for your research use or educational purposes in electronic or print form. You must obtain permission for any other use. Electronic or print copies may not be offered, whether for sale or otherwise to anyone who is not an authorised user. 


\title{
What is Project Strategy?
}

\author{
Authors: \\ Artto, Karlos, Prof. (corresponding author) \\ Helsinki University of Technology \\ Industrial Management \\ P.O. BOX 5500, FI-02015 HUT, Finland \\ Tel: + 35894514751 \\ Email: karlos.artto@hut.fi \\ Kujala, Jaakko, Dr. (Tech.) \\ Helsinki University of Technology \\ BIT Research Centre \\ P.O. BOX 5500, FI-02015 HUT, Finland \\ Tel: + 3584048391717 \\ Email: jaakko.kujala@hut.fi \\ Dietrich, Perttu, M.Sc. \\ Helsinki University of Technology \\ BIT Research Centre \\ P.O. BOX 5500, FI-02015 HUT, Finland \\ Tel: + 358503853490 \\ Email: perttu.dietrich@hut.fi \\ Martinsuo, Miia, Dr. (Tech.) \\ Helsinki University of Technology \\ Industrial Management \\ P.O. BOX 5500, FI-02015 HUT, Finland \\ Tel: + 358504302723 \\ Email: miia.martinsuo@hut.fi
}




\title{
What is project strategy?
}

\begin{abstract}
The concept of project strategy - referring to the strategy of a single project - has remained ambiguous in existing studies. In this research we review literature from multiple viewpoints to develop a novel definition and interpretation about the project strategy concept. Our definition is used to derive different alternative project strategies from literature, characterized by two important dimensions in a project's environment: project's independence and number of strong project stakeholder organizations. We introduce four types of strategies for a project along these two dimensions: obedient servant, independent innovator, flexible mediator, and strong leader. Existing research using the project strategy concept mostly assumes that there is one strong parent organization for a project; indeed, the parent is assumed to dictate an image of its strategy to the project, and the project is assumed to take an obedient servant's role, to serve as a tactical vehicle that becomes a mere part of its parent organization and the parent's strategic scheme. Our project strategy definition and the four project strategy types allow a more open interpretation about the content of alternative environment-dependent project strategies as well as the processes of strategy formulation and implementation. The wider concept of project strategy introduced in this paper recognizes more widely the various positions that a single project may take in its environment. This way, our paper contributes even to development of new and context-specific project management bodies of knowledge in the future. The paper suggests empirical research and further conceptual research on detailed contents of different project strategies.
\end{abstract}

Keywords: project strategy, project business, project management 


\section{Introduction}

Current project management literature on strategy of an individual project - or project strategy - mainly considers that project strategy is mostly about goals and plans. Existing research suggests that such goals and plans are aligned with parent organization's strategy. However, it is not always appropriate that one parent organization dictates project's goals or sets the success criteria from outside the project. It is not always feasible that a project serves as its parent organization's obedient servant while copying an image of its parent's strategy to something that is called project strategy. Indeed, in existing project strategy studies projects are assumed to take a fairly tactical role as non-strategic and non-self-directed vehicles in one parent firm's context. The existing literature uses a much too narrow perspective when assuming that projects' strategies consist of plans or plan-like descriptions, such strategies are created in the front end of the project, such strategies are dictated always from outside the project rather than allowing the project itself to take a position in its environment, and such strategies are static rather that dynamic in their nature.

Goals for the project as well as project management approaches of the different stakeholders may vary a lot. Due to the inherent complexity of multi-stakeholder projects, projects must take into account multiple stakeholders' interest in their goal setting. Projects cannot just directly adopt only one uniform and explicit goal or method communicated by a top management representative of a single parent organization. In fact, the project must carefully position itself to its environment, and the goals and management methods of the project must be carefully matched with the situation at hand and the context. Such approaches are contained in the concept of project strategy.

The objective of this paper is to define the concept of project strategy and characterize different project strategy types based on analytical reasoning and synthesis from existing literature. As far as the research strategy of this paper is concerned, we consider a project as a temporary organization (for discussion about projects as temporary organizations, see, for example [1], [2]). This perspective on a project (as an organization) allows us to draw analogies between projects and any other types of organizations. The ancient military strategy knowledge and early strategic management literature emphasize the relative position of an organization in its external competitive environment, with emphasis on activities necessary to 
achieve a desired position [3]. As the strategy of a firm relates to the firm's aspirations to achieve a desired position in its competitive external environment, the strategy of a project relates to the project's aspirations to achieve a desired position in its competitive stakeholder environment. When defining project strategy, the existing literature only seldom recognizes the following obvious fundamental issue that comes with the basic concept of strategy: if the project (as a temporary organization) has a parent organization, then - from a project strategy viewpoint - also the parent organization's internal environment must be interpreted as part of the project's external (not internal) environment. In order to understand project strategy, we need to understand the project's position in its external environment and the possible pursuit to alter such a position. This perspective serves as a foundation for our approach to apply generic concepts and research on strategy to answer the research questions: "What is project strategy?"

\section{Earlier literature on project strategy}

In this paper we use project literature, referring explicitly or implicitly to the concept of project strategy. In fact, we found only one source that provided a concise explicit definition of project strategy [4], and this definition was adopted by another source as a point of departure for an empirical study [5]. In some other sources there are attempts to explicitly define elements of project strategy $[6,7,8,9]$. However, most of these studies define project strategy in an implicit and ambiguous way, by rather discussing the process of formulating the strategy without defining what the strategy is. Then, there are many project studies that use the term 'project strategy' or just the term 'strategy' occasionally, with no particular meaning nor any specific emphasis on its content. We have also taken a look at project studies with general references to 'strategy' or 'strategic' issues, to include them in our literature analysis when appropriate. The large project studies included in our literature analysis are good examples of such studies that discuss strategies of single projects, although they have mostly referred to concepts such as 'strategic project management' rather than project strategy. Finally, as programs are argued often to be more strategic than projects, we also have looked at program management literature for analogous concepts, like program strategy or strategic program management. However, the program management literature did not stand out in this study as literature that would have particularly elaborated the strategy of a single program. 
We identified three dominant tracks of project literature, referring explicitly or implicitly to the concept of project strategy (see Table 1). In the first and most dominant track, projects are viewed as subordinate to the parent organization where project strategy is derived from more significant business strategies of the parent. This literature track tends to use the project strategy term explicitly whereas the other tracks mostly refer to the concept only implicitly. This literature track mostly suggests that project strategy consists of a mere static plan or predetermined goals for the project.

In the second track with somewhat fewer literature sources, projects have been considered as autonomous organizations connected loosely or tightly to a parent organization. In such literature, projects themselves develop their own strategies and plans independent of the surrounding organizational context.

In the third track, projects have been considered as organizations that are not subjected to clearly defined governance or authority setting in relation to their surrounding organizations or stakeholder organizations. In such cases, projects interact with their uncertain and complex environment and adapt to the ongoing changes as strategic entities of their own. This track dominantly includes studies on large projects that rather discuss strategic project management related to success and failure issues, rather than project strategies. Table 1 summarizes central literature on each of the three literature tracks and their main contributions identified. The following chapters explain the contents of each of the three literature tracks in more depth. 
Table 1. Summary of literature on the concept of project strategy

\begin{tabular}{ll}
\hline $\begin{array}{l}\text { Literature track } \\
\text { Examples of sources }\end{array}$ & $\begin{array}{l}\text { Main contribution to project strategy concept } \\
\text { and potential research gaps }\end{array}$ \\
$\begin{array}{l}\text { project strategy } \\
\text { viewpoint }\end{array}$ &
\end{tabular}

Project as $\quad[10,11,7,12,6,13,14$,
subordinate to a $\quad 15,8,4,5,16]$
parent
organization
This literature concentrates on project strategy formulation through a top-down process starting from the parent organization's business strategy. As this strategy formulation process is fixed, the project is not allowed to form its strategy independently, but the project's strategy is an image of the parent organization's strategy and the project is in a role of implementing its parent's strategy. Project strategy is a static plan (or predetermined management approaches like guidelines or attitude/perspective given to the project) that is formulated in the front end stage of the project. The elements of project strategy are explained either through their inclusion into specific standard project management processes, or through copying/translating component parts of the firm's strategy to the project, such as e.g. positioning of the firm's product in the external competitive market landscape, or competitive advantage in this external marketplace. This literature concentrates on the parent's and its project's activities in parent's external environment, and parent organization's internal environment is not considered as the external environment for the project that would affect the project's strategy. 
Project as an

autonomous

organization but

connected to a

parent

organization
[27, 23, 22, 24, 28, 26, 9, This literature has two distinct conceptions of $25]$ project strategy. First, a project carries within its boundaries significant responsibility for the business that it is expected to establish, and accordingly, the project is authorized and resourced to choose and implement its directions independently. Second, the project's strategy is seen as project execution strategy, where the project's authority is limited to independent strategies in project execution and in project management, but not in the actual overall business content/result that the project is expected to implement.

Project in a $[31,34,50,35,46,36$, This literature sees the project as an complex environment $37,38,39,40,44,47,45$, 41]

with unclear

overall

governance

scheme organization/entity that is positioned in a complex organizational environment with several powerful stakeholders, and not just one powerful parent organization. Project strategy of such project relates to the project's adaptation to its environment. This literature assumes that project strategy is self-originated and it is related to the project's own governance structure; the project includes within its boundaries all management levels of any successful and independent enterprise (institutional/strategic, middle management, technical-tactical levels). 


\section{Project as Subordinate to Parent Organization}

Cleland [10] defines strategic management as "the management of the organization as if its future mattered." Shenhar et al. [4] argue that strategically managed projects are focused on achieving business results, while operationally managed projects are focused on getting the job done. Project strategies and plans are typically presented as part of a hierarchy of strategies, objectives and plans for a company $[11,6]$. The dominant assumption is that the project belongs under the control of one strong parent organization $[11,7,12,6,13,14,8,15$, $4,6,16]$. This literature introduces processes for creating the project strategy by feeding it from the parent organization $[13,14,8,15]$.

This literature track assumes that the strategy is created in the front end phase of the project, and that the project strategy is a static plan-like representation, explicitly documented in project documents. Such project strategies (as plans) are mostly used for agreeing about project goals at the firm level and for providing guidelines for how to execute the project's work in a firm's business context, rather than for representing self-established or selfcontained business strategies of the temporary organization of a single project [17] for discussion on firm's strategy implementation by projects, [18] for strategic management of multiple projects, [19] for management of project-based firms, and [20] for project business. This occurs as there is not much freedom for the project to derive the project's goals autonomously or to use other mechanisms for strategy creation than the one dictated by the parent company, but the project's goals and strategies are given or strongly constrained by one strong stakeholder (the parent organization) from the project's external environment (see $[21,22]$ for environment-dependent approaches in projects).

In this track of literature, the project's assumed approach and strategy in its existing environment is limited by the assumption that the project must obey its parent organization's directions and implement the parent organization's business strategy. The project is not assumed to be independent of its parent, and the parent seems to be the most dominant single stakeholder whose interests the project must continuously follow. With such assumptions, the mere strategy a single project remains to serve its parent as a servant and to conform to the parent organization's ways of operating. These assumptions imply that projects are at tactical level, as compared to the strategic activities at the senior managers' level that are positioned outside the project's boundaries to a higher level in the parent organization's hierarchy. 
Understanding project strategy through its elements derived from standard project management practice $[13,14,15,8]$, or from components of parent organization's strategy [4, 5] is a good addition to describe the anatomy of project strategy. However, we see that the suggestions of project management elements, or parent organization's strategy components and project management approaches, models, or guidelines brought into the project as parts of its strategy, make further limitations about what the nature of an individual project's strategy could be. Therefore, the project strategy research should allow research on how projects could carry out entire parts of the firm's businesses if necessary, and not just emphasizing the aspect of how project execution (and respective project management elements) could be in full service to support the implementation of a parent firm's strategy (and respective strategy components of the firm).

\section{Project as an Autonomous Organization but Connected to Parent Organization}

There is literature that recognizes implicitly the existence of an own business-contained project strategy or self-established project strategy of an individual project [22, 23, 24]. Loch's [22] study of product development projects of a European technology manufacturer provides an excellent example of how each project carried a true business content within the boundaries of the project. This emphasizes that the projects themselves could independently carry a business strategy within their boundaries, in constant contact with their dynamic context. Such business strategies within the boundaries of autonomous projects could be created within the project on an independent basis, even without too much feeding from the business strategy of the project's parent organization. McGrath [23] introduce an organizational model for autonomous - or authorized - product development projects that independently carry end-to-end responsibility of the actual business related to the new product. McGrath \& MacMillan [24] introduce discovery-oriented project management approach for product development projects with uncertain outcomes. This approach reflects autonomy of a single project with certain kind of internal structure and processes to create its relevant content and outcome independently in its environment.

There is literature that sees the project's strategy as project execution strategy, where the project's authority is limited to choosing and implementing strategies in project execution and 
in project management, but not in the actual overall business content/result that the project is expected to implement $[9,25,26]$. Pulkkinen [9] defines the model of project execution strategy that includes execution related critical success factors that are made in the project planning phase. Even though the project execution strategy does not help much to achieve the higher levels of project success, it is essential especially for project suppliers whose businesses are focused on project deliveries. Also Lam et al. [25] introduce a rather execution-oriented project management strategy of design-build projects in construction. Arnaboldi et al. [26] illustrate 'project management strategy' that includes organizational issues and approaches for the strategic management of a large organizational change project. Finally, there are studies that consider project's strategies as project's internal choices of approach, management method, product concept or scope from alternative strategic options in contingent situations. Such choices may relate, for example, to planning strategy [27], to culturally responsive strategies in project management [28], to contract strategy [29], or to teaming strategies in a construction project [30]. This literature focuses on the autonomous nature of project organizations in executing the project, and project strategy as the way forward in that temporary organization. Such literature not only considers goals and plans, but also choices regarding the project's unique ways of operating.

In this track of literature, projects are easily treated not only as autonomous but also as isolated entities. The isolation is apparent in the deficient use of managerial levels. Even if three principal levels of management have been identified for projects - institutional, operative, and tactical [31] - most project management literature deals only with operative and tactical level project strategies. There is little in the literature dealing with institutional level strategy concerning the project's positioning in its broader context. We would encourage environment-dependent strategies of autonomous projects that would not be restricted by isolation of the project (see [32] for continuous change in the environments of organizations and projects). Furthermore, we see that the emphasis on project execution - or execution strategies - could introduce sometimes even a too static setting to the nature of what a project's strategy is. We would recommend also considerations of project strategies that would allow for dynamic content of the strategy (see [33] for dynamic contents of strategy). 


\section{Project in a Complex Environment with Unclear Overall Governance Scheme}

There is literature on empirical and empirically based conceptual studies on large projects embedded in their complex and dynamic contexts [34, 35, 36, 37, 38, 39, 40, 41]. This literature recognizes implicitly the existence of an own project strategy or self-established project strategy of an individual project. In this literature, turbulence in the project's environment, dynamism, uncertainty and complexity tend to be important issues that affect the project and its strategy. Floricel and Miller [42] propose a conceptual framework, grounded in the study of the large-scale engineering projects, which attempts to theorize the strategic management of large-scale projects in the context of uncertainty and turbulence. Morris [31] describes the turbulent environment in projects by emphasizing the extreme goalorientation, high conflict, vague roles, constantly changing priorities, and invariably conflicting objectives. Lampel [43] emphasizes the autonomous processes within a single project by describing a project as a life-organism. This description may even be interpreted to imply that the project would independently continue to conduct its activities in different forms that depend on the challenges caused by the project's environment and various situational factors.

The above-mentioned large project studies suggest a more independent management of the project by including a self-directed definition of its outcome into the project's management scheme. This kind of business-contained project strategy differs from the project execution type of strategy, where the project's strategy would be derived or created from the business strategy of the parent organization, and the project serves as a mere extension of its parent, with a task to implement its parent broader strategies. Many empirically researched large projects are public projects that are planned and executed in a consortium of several players and the projects are impacted by political decision making bodies. Such large projects do not always engage one strong customer or owner organization, but there may be several parties even with conflicting interests that represent owners (or an owner consortium).

Samset [44] introduces the strategy of a single project through introducing the interrelated key elements of project strategy that include strategic, tactical and operational objectives, and main contextual uncertainties with each objective. Kolltveit et al. [45] emphasize the importance of strategic choices concerning project's scope from alternative scopes with different profitability and uncertainty profiles. Milosevic [46] defines strategic project 
management as management that addresses improving of project results. Furthermore, Milosevic introduces a systems model of strategic project management controlling the environmental elements usually referred to as the external project stakeholders. Pitsis et al. [47] introduced "future perfect" strategy as a new conception to manage a project. Pitsis et al. [47] argue that managing through the future perfect is an approach to strategic management that occurred in a context where planning was practically impossible.

Studies in this track of literature analyze the creation and implementation of strategies of individual large projects from a more project-originated perspective, where the project must take into account its environment and circumstances in a more self-directed way. The track record of these projects is fundamentally poor, and the large project studies analyze issues that are related to risk and success. These studies often take a departure of understanding project success and how successful outcomes are achieved from the project.

The project strategy for such large projects can be considered to be partly derived from the success discussion. The success issue relates to different stakeholders. The various stakeholders' different objectives, interests, and needs add to the complexity of managing a project [48]. The governance and shaping of the project in its complex environment with several stakeholders relate to project strategy [37]. No project can exist in isolation from outside events. Projects as temporary organizations have to be viewed as open systems [1] that are constantly interacting in and with their dynamic context [49]. Concerning the management levels in a project, the large/complex project literature assumes that the project's own governance structure and organization includes within the project's boundaries all management levels of any successful enterprise [31]. The organizational structure of the project seems to be relevant from the project strategy point of view, and so is the recognition of the dynamism and necessary continuous changes in the organizational structure and changes in the emphases of the project management levels in different phases during the project lifecycle [31]. Slevin \& Pinto [50] concluded that both project's strategy and tactics are important for a project's success, and they emphasize the dynamic nature of the project's strategy. According to Slevin \& Pinto, at no point do strategic factors become unimportant to project success. Instead, they must be continually assessed and reassessed over the life of the project in light of new project developments and changes in external environment. 


\section{Definition of project strategy}

Based on the above analysis, we conclude that the concept of project strategy should not be limited to serving a single parent organization only. Instead, the concept of project strategy should acknowledge a project's autonomy as well as its unique position as part of its complex context. Concerning the levels of project management ([31], referring to [51]), a project strategy should concern not only operative and tactical levels, but also the institutional level, and thereby enable a project's significant interaction with its context. This broader viewpoint would allow the project to define and implement a strategy of its own in alignment with the project's unique environment. Therefore, a more holistic project strategy concept should be developed, to take into account a project's possibility to operate as an autonomous organization, to seek survival and success in an uncertain and complex environment, and to consider strategic options possibly with multiple strong stakeholders. However, it is important that the definition of project strategy is generic enough, to allow also for project's choices that are in accordance with suggestions in the existing project strategy literature: the definition must allow situations where the project's choice is to respond to its parent's will obediently. Based on our literature analysis above, we conclude a generic project strategy definition:

"Project strategy is a direction in a project that contributes to success of the project in its environment."

Our project strategy definition is designed to allow for different kinds of project strategies that individual projects may have. In order to clarify the meaning and importance of this definition, we explain the words direction, contribute, success, and environment in our definition:

- We selected the word direction to describe explicit elements of the project strategy. It can be interpreted as either one or several of the following: goals, plans, guidelines, means, methods, tools, or governance systems and mechanisms including reward or penalty schemes, measurement, and other controlling devices. We assume that all these elements include a capability to directly or indirectly affect the project's course. Project's "direction" and its elements may change even on a continuous basis in a project, which suggests that project and its strategy is dynamic. 
- Contribute refers to the assumption that the "direction" has an effect i.e., it matters and makes a difference.

- Success refers to how well the project is able to accomplish its goals. Each project stakeholder may have different and conflicting criteria for evaluating project's degree of success. However, our definition also allows an interpretation that project can be successful by meeting its self-established goals that may be against the interest of most or even all major stakeholders. A project's success may in some situations relate to project's capability to survive in its hostile environment until it has accomplished its tasks and the temporary project organization is dissolved. This survival aspect to success refers to the question whether project is able to compete against other projects, obtain access to necessary resources and continue to exist in order to become successful.

- Environment refers to the world outside the project's boundaries with which project as an open system must continuously interact. Thus, also the project's parent organization and other stakeholders belong to project's environment. The boundary between project and its environment is dynamic and in constant change as project organization integrates external resources into its organization.

Project strategy, or any generic organizational strategy, is related to competitive advantage or survival of the organization in its external environment (see for example [64]). From a project's point view, criteria for measuring survival and success and respective managerial actions may be quite different in different phases of the project and for different types of project strategies. For example, in the initiation phase, the project must be able to demonstrate its advantage compared to other investment options or competing solutions. In the latter phases of the project, the success or survival may come from ensuring access to necessary resources to implement the project.

\section{Types of Project Strategy}

Strategies of single projects relate to a project's position in its environment. Based on our literature analysis above, we can conclude that project strategy is influenced by how autonomous a position the project takes towards its parent organization, and how it positions itself compared to its other strong stakeholders. Project's parent organization represents a 
strong stakeholder, but a project can have also several other strong stakeholders. There even can be several parents or parent-like organizations. This occurs e.g. in a joint project that is a partnerhip-based venture of several organizations, or in a project with several business or nonbusiness stakeholders that serve in various owner, customer, user and sponsor roles, each often with their strong and even conflicting interests concerning the ultimate outcomes of the project (see, for example, large project studies: [34, 35, 36, 37, 38, 39, 40, 41].

According to Lampel \& Jha [52], project autonomy refers to the degree to which the project is allowed to evolve without constant report and input from the parent organization. Most project strategy definitions and interpretations in the existing literature assume that a project is not autonomous, but the project is run under a strong governance of one parent organization. Our interpretation of project autonomy is not restricted only to cover autonomy in relation to the project's one parent organization, but we rather use the concept of independence that reflects the autonomous position of project's relationships to other stakeholders that all may either restrict or allow for autonomy to the project.

Based on our analysis of existing research, we conclude that the degree of project's independence and the number of project's strong stakeholders are important parameters in the project's environment that can be used to explain different strategies in projects. We suggest four distinct types of project strategies: obedient servant, independent innovator, flexible moderator, and strong leader. In Figure 1 we show these four different types of strategies project can take along the dimensions of project independence and number of strong stakeholders/parent organizations. The four project strategy types are explained in the following, in terms of the direction and success issues of our project strategy definition. 
Figure 1. Four obvious project strategies depending on project's independence and number of strong project stakeholder organizations

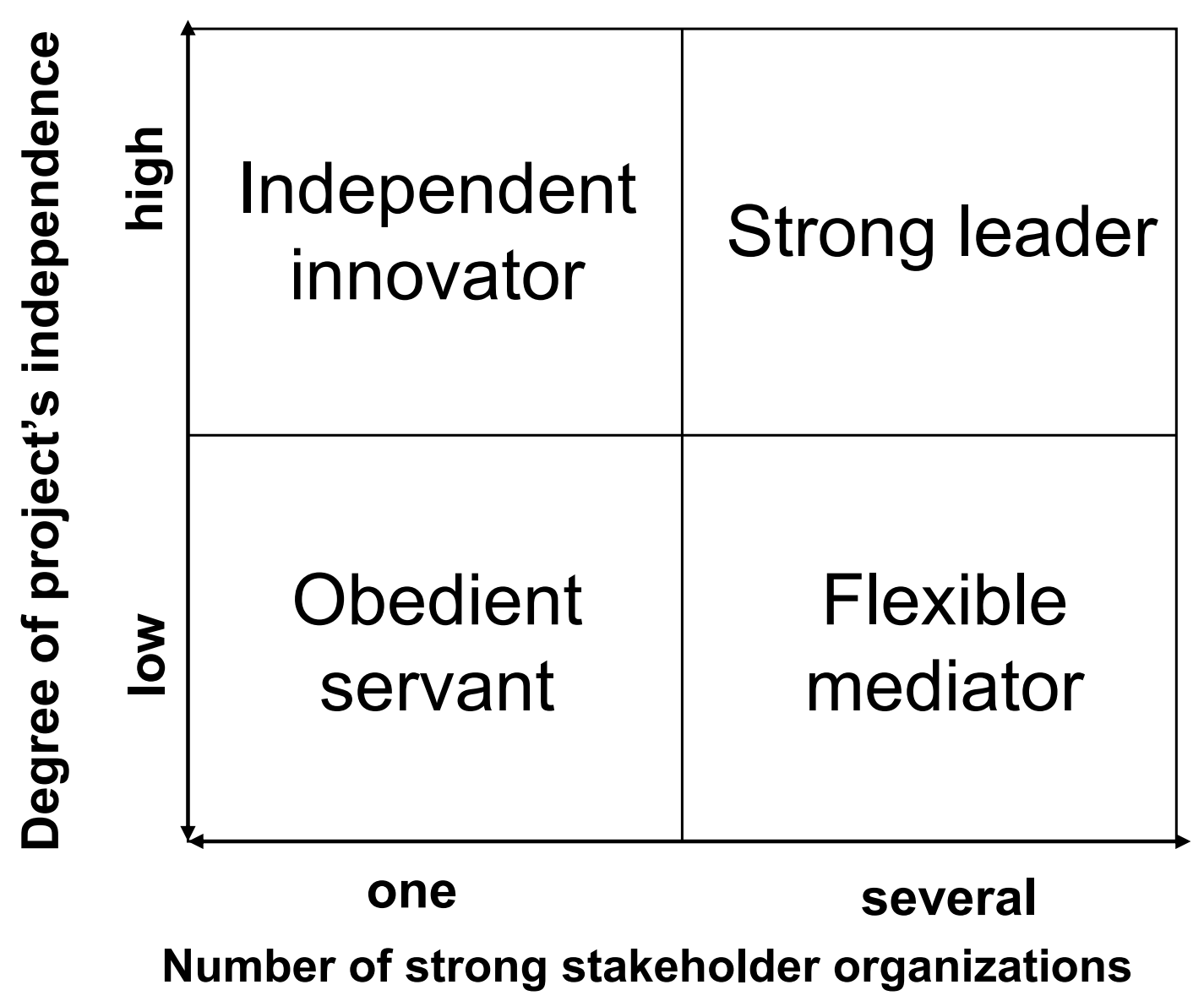

Project with obedient servant strategy considers its parent organization as the most important stakeholder in its environment. Project exists for its parent and the objective for the project is to fulfill its parent's will. An obedient servant strategy may result to the project's success due to an appreciation of the parent organization, measured by how well the project implements and supports the parent's business strategy.

Project with independent innovator stategy establishes its direction by encouraging innovative and independent behavior for finding or maintaining the project's own business content and purpose. Project joins with such parts of the parent organization (e.g. sponsors) or other stakeholders that help to advance the project's purposes, but it simultaneously competes, 
fights or hedges against such parts of the parent or other stakeholders that pose a threat to the project's purpose. The success of an independent innovator strategy may be measured through newness, degree of change, or impact related to the project's outcome, or even through the project's capability to renew or change its parent's business strategy.

Project with flexible mediator strategy finds its direction by defining its operating environment as that among the group of several strong stakeholders. The project adapts to its stakeholders' goals and objectives set for the project, to stakeholders' standards of practice, and potentially to the industry practice that the stakeholders represent. The success of a flexible mediator may be measured by the synergy that the project could create among stakeholders' participation, by the level or number of feasible compromises among the stakeholders, or simply by the project's survival in the complex setting of multiple stakeholders with different and conflicting objectives and standards of practice.

Project with strong leader strategy selects its direction by creating a strong independent culture and feeling of the importance of making the project successful. This means that the project establishes and adjusts its own goals and objectives in its stakeholder network. The project is organized from inside out by creating a governance umbrella where stakeholders are positioned in purposeful roles while some stakeholders may even be deliberately excluded from the overall governance scheme. The success of a strong leader strategy may be measured by the project's internal capability of creating a unique view of perceiving the world and establishing purposeful goals and objectives for the project, capability of using specific stakeholders as resources, and capability to change stakeholder salience (or stakeholders' power to influence the project). These kinds of success issues are necessary for the ultimate success measured by the overall impact of the project to the society and its environment as whole, and not by whether the project contributes to strong stakeholders' businesses.

\section{Conclusion}

In the existing literature, a project's approach to its existing environment in its strategy is often limited by the assumption that the project must obey its parent organization's directions and the parent organization's business strategy, respectively. In fact, these assumptions in the existing literature enforce adopting a viewpoint where a project is not necessarily an 
independent temporary organization but just a part or an extension of the parent organization. This conceptual narrowness in project strategy definitions leads to empirical studies that just analyze strategies of individual projects as if they would be the same as the respective strategies of their parent organizations.

In this research we have reviewed an extensive set of literature on project strategies from multiple viewpoints and developed a definition for project strategy, which allows a more open interpretation about the content of the strategy. Based on our literature analysis, we introduced four alternative environment-dependent project strategies, differentiated by different degrees of project's independence, and the number of strong stakeholders as important parameters in a project's environment. By suggesting a definition for the project strategy and introducing four project strategy types, this paper contributes to new knowledge in a rather significant manner. There are two major reasons for this. First, proper project strategy definitions are lacking in the existing literature. Second, in existing literature, there are many different kinds of conceptions of what project strategy is, and each conception seems to be either too narrow or too context-specific to serve as a generic definition for different kinds of strategies that exist in live projects. The project strategy definition we suggested in this paper:

- Focuses on understanding of the project strategy in different contexts characterized by one parent organization or several strong stakeholders, and different degrees of project independence.

- Allows for various interpretations of strategy, where strategy can be a plan-like description created in the front end of the project life cycle, but it can also be some other scheme - for example, a self-originated scheme within the project - that would provide direction to the project.

- Allows for both an assumption that project strategy would be a set of static objectives, plans, procedures or mechanisms, and an assumption that project strategy would be a dynamic scheme.

- Does not assume any specific types of pre-determined processes for project strategy formulation or implementation, but allows also an assumption that project strategy could be created continuously throughout the whole lifecycle of the project.

- Assumes that the project's strategy is own and original strategy of the temporary project's organization. As the project's organization is a different entity from its 
parent's organization that belongs to the project's external environment. the basic assumption is that the project's strategy is different from its parent's strategy independently of the fact whether parent's and project's strategies are not aligned, or aligned by using specific processes for strategy definition and alignment.

\section{Themes for future research}

The generic definition of project strategy introduced in this paper provides a fruitful foundation for further research. Such further research should take into account the dynamic nature of the project strategy, meaning that strategies are dynamically created and they also change during the project life-cycle. We suggest future research on the following six themes.

First, the practical value of the four types of strategies, created in this paper based on synthesis of existing research, should be shown by empirical research. What is the more specific nature of each of the four different project strategies? Which strategies are the most appropriate in different contexts, i.e., what are their real success factors? What risks are related to different project strategies? Empirical case projects and their strategies should be positioned into the framework characterized by the degree of project's independence and the number of project's strong stakeholders, and their strategies should be analyzed. Such empirical studies would deepen understanding on: what kinds of strategy contents do single real-life projects have in their specific contexts; how and why projects perceive their environments; and how such perceptions justify or lead to such selected strategy contents.

Second, research on project strategy formulation and implementation is needed. What are the routes through which successful project strategies emerge? The positioning of the project into the classification of four types of project strategies shown in Figure 1 may imply specific processes of strategy formulation and strategy implementation, addressed by the process view on strategy (for the process view, see e.g. $[53,54,55,56,57,3,58,59,60,61,62,63]$. For example, in case of the obedient servant strategy, the strategy formulation is reflected by interpreting the project strategy as the "missing link" between parent organization's business strategy and project implementation plans [4]. Project strategy formulation and implementation of an independent innovator may even involve gameplaying and politics 
among the project's supporters and adversaries. A flexible mediator formulates a strategy that balances various needs of different stakeholders and compromizes across different stakeholders' interests. A strong leader project carries its responsibility to select a direction and organizing the project from inside out independently, by taking its environment and stakeholders into account while doing this.

Third, further research is proposed on the evolution and dynamics of project strategies. Empirical studies should address especially factors that determine what kinds of positions a project may take in relation to its external environment and how that position changes during the project lifecycle. From this perspective, project strategy can also become a path to change project's position, e.g. to gain more autonomy. This also raises the question about who are the strategists in projects, also relevant as a topic of future research. How the project perceives the outside world at certain points of time, would influence the project strategy, and accordingly, the dynamism in the project of shifting from one strategy to the next across different phases in the project lifecycle.

Fourth, research is needed on different project strategies in different environments. For example, conceptual literature research using a specific literature base in a different application area (e.g. innovation, organizational change, process development or IT system implementation) should be conducted to address strategies of single projects. Furthermore, empirical research is needed on specific project types of e.g. innovation projects, equipment delivery projects, capital investments projects, systems integration and IT projects, and construction projects. Also, future research should take a closer look at projects from different industries, to understand potential industry-specific practices and their implications on project strategies.

Fifth, we suggest that project strategy research should seek support and further avenues through mainstream strategy research and through operations management literature. As far as the strategy research is concerned, future research should explore connections between projects', parent organizations' and stakeholders' strategies, to better understand the emergence of strategies in projects as temporary organizations. Exploring how temporary organizing has been treated in mainstream strategy literature could reveal explanations to successes and failures of projects in their broader business context. 
Sixth, a stakeholder perspective on project strategy represents one specific research theme, with an aspect of understanding how project strategy is formulated and implemented, and how it evolves across a network of several stakeholders, each with different and even conflicting objectives concerning the project at hand. Which kind of approaches do project stakeholders use in the different phases of the project to influence project strategy? Which factors determine whether project strategists take into account stakeholders' strategies and interests in the formulation and implementation of project strategy? What are successful approaches for managing multi-stakeholder project strategy creation process?

\section{References}

[1] Lundin, R. A. Temporary organizations and project management. Scandinavian Journal of Management 1995;11:315-318

[2] Lundin, R. A., Söderholm, A. A theory of temporary organization. Scandinavian Journal of Management 1995; $11: 437-455$

[3] Chaffee, E. E. Three models of strategy. Academy of Management Review 1985; 10: 8998

[4] Shenhar, A. J., Dvir, D., Guth, W., Lechler, T., Patanakul, P., Poli, M., Stefanovic, J. Project strategy: the missing link. Paper presented in 2005 Annual meeting of the Academy of Management in the 21st Century, Honolulu, HI, 2005.

[5] Patanakul, P., Shenhar, A. J., Milosevic, D. Why different projects need different strategies. Proceedings of the PMI Research Conference 2006, Montreal, Canada, July 16-19, 2006. Pennysylvania: Project Management Institute, 2006.

[6] Turner, J. R. The handbook of project-based management: Improving the processes for achieving strategic objectives (2nd ed.). London: McGraw-Hill Companies, 1999.

[7] Wheelwright, S. C., Clark, K. B. Revolutionizing product development: quantum leaps in speed, efficiency, and quality. New York: Free Press, 1992.

[8] Morris P., Jamieson A. Translating corporate strategy into project strategy: realizing corporate strategy through project management, Newtown Square, Pennsylvania: Project Management Institute, 2004. 
[9] Pulkkinen, V-P. Project Execution Strategies for EPC Power Plant Contractors, Master's Thesis. Helsinki University of Technology, Department of Industrial Engineering and Management, 2005..

[10] Cleland, D. I. Strategic management: the project linkages. In: Morris P. W. G. and Pinto J. K. (eds.): The Wiley Guide to Managing Projects, 206-222. London: John Wiley \& Sons Inc, 2004.

[11] Cleland, D. I. Project management: strategic design and implementation. Blue Rigde Summit, PA: TAB Books Inc, 1990.

[12] Griffin, A., Page, A. L. PDMA Success Measurement Project: Recommended Measures for Product Development Success and Failure. Journal of Product Innovation Management 1996; 13: 478-496

[13] Anderson, D. K., Merna, A. Project Management Strategy-project management represented as a process based set of management domains and the consequences for project management strategy. International Journal of Project Management 2003; 21: $387-393$

[14] Anderson, D. K., Merna, A. Project Management is a Capital Investment Process, Journal of Management in Engineering 2005; 21: 173-178.

[15] Jamieson, A., Morris, P. W. G. Moving from corporate strategy to project strategy. (pp. 177-205) In: Morris P. W. G. and Pinto J. K. (eds.). The Wiley Guide to Managing Projects, 177-205. London: John Wiley \& Sons Inc, 2004.

[16] Milosevic D. Z., Srivannaboon S. A theoretical framework for aligning project management with business strategy. Project Management Journal 2006; 37(3): 98-110

[17] Artto, K. A., Dietrich, P. H., Nurminen, M. I. Strategy Implementation by Projects. In: Slevin, D.P., Cleland, D.I. and Pinto, J.K., (eds.): Innovations: Project Management Research 2004, Newtown Square, Pennsylvania, Project Management Institute, 2004.

[18] Artto, K. A., Dietrich, P. H. Strategic Business Management through Multiple Projects. In: Morris P. W. G. and Pinto J. K. (eds.): The Wiley Guide to Managing Projects, John Wiley \& Sons Inc, London, 2004.

[19] Whitley, R. Project-based firms: new organizational form or variations on a theme? Industrial and Corporate Change 2006; 15: 77-99

[20] Artto, K. A., Wikström, K. What is project business? International Journal of Project Management 2005, 23(5), 343-353.

[21] Emery, F. E., Trist, E. L. The causal texture of organisational environments. Human Relations 1965;18:21-32. 
[22] Bettis, R. A., Hitt, M. A. The new competitive landscape. Strategic Management Journal 1995;16:7-19.

[22] Loch, C. Tailoring product development to strategy: Case of a European technology manufacturer. European Management Journal 2000;18: 246-258

[23] McGrath, M. E. (ed.). Setting the PACE in product development: a guide to product and cycle-time excellence, Boston: Butterworth-Heinemann, 1996.

[24] McGrath, R., G., MacMillan, I. The Entrepreneurial Mindset: Strategies for Continuously Creating Opportunity in an Age of Uncertainty, Boston: Harvard Business School Press, 2000.

[25] Lam, E. W.M., Chan, A. P.C., Chan D. W.M. Benchmarking design-build procurement systems in construction. Benchmarking: An International Journal 2004; 11; 287-302

[26] Arnaboldi, M., Azzone, G., Savoldelli, A. Managing a public sector project: the case of the Italian Treasury Ministry. International Journal of Project Management 2004; 22: $213-223$

[27] Bryson, J. M. , Delbecq, A. L. A Contingent Approach to Strategy and Tactics in Project Planning. American Planning Association Journal 1979; 45: 167-179

[28] Milosevic, D.Z. Selecting a culturally responsive project management strategy. Technovation 2002; 22: 493-508

[29] Chan, E. H.W., Yu, A.T.W. Contract strategy for design management in the design and build system. International Journal of Project Management 2005; 23: 630-639

[30] Dzeng, R., Wen, K. Evaluating project teaming strategies for construction of Taipei 101 using resource-based theory. International Journal of Project Management 2005; 23: $483-491$

[31] Morris, P. W. G. Project organizations: Structures for managing change. In: Kelley, Albert J. (editor), New dimensions of project management, Arthur D. Little Program, Lexington, MA: D. C. Heath and Co., 1982

[32] Brown, S. L., Eisenhardt, K. M. The art of continuous change: Linking complexity theory and time-paced evolution in relentlessly shifting organisations. Administrative Science Quarterly 1997;42: 1-34.

[33] Eden, C., Ackermann, F. Making strategy. The journey of strategic management, Sage Publications, London, 1998.

[34] Kharbanda, O. P., Stallworthy, E. A How to Learn from Project Disasters -True-life Stories with a Moral for Management. Hampshire, United Kingdom: Gower Publishing Company, 1983. 
[35] Morris, P. W. G., Hough, G. H. The Anatomy of Major Projects - A Study of the Reality of Project Management, Chichester: John Wiley \& Sons, 1987.

[36] Kharbanda, O. P., Pinto J. K. What Made Gertie Gallop? Lessons from Project Failures. New York: Van Nostrand Reinhold, 1996.

[37] Miller, R., Lessard, D. The strategic management of large engineering projects: shaping risks, institutions and governance. Cambridge: MA: MIT Press, 2001

[38] Miller R., Lessard D, Understanding and managing risks in large engineering projects. International Journal of Project Management 2001,19: 437-443

[39] Williams, T. Modeling Complex Projects. John Wiley \& Sons, 2002.

[40] Flyvbjerg, B., Bruzelius, N., Rothengatter, W. Megaprojects and Risk: An Anatomy of Ambition. Cambridge: Cambridge University Press, 2003.

[41] Grün, O. Taming Giant Projects: Management of Multi-Organization Enterprises. Berlin: Springer, 2004.

[42] Floricel, S., Miller, R. Strategizing for anticipated risks and turbulence in large-scale engineering projects. International Journal of Project Management 2001, 19: 445-455

[43] Lampel, J. The core competencies of effective project execution: the challenge of diversity. International Journal of Project Management 2001; 19: 471-483

[44] Samset, K. Project Evaluation. Making investments succeed. Trondheim: Tapir Academic Press, 2003.

[45] Kolltveit, B. J., Karlsen, J. T., Grønhaug, K. Exploiting Opportunities in Uncertainty During the Early Project Phase. Journal of Management in Engineering 2004, 20(4)

[46] Milosevic, D. Z. Systems approach to strategic project management. International Journal of Project Management 1989; 7: 173-179

[47] Pitsis, T. S., Clegg S. R., Marosszeky, M., Rura-PoUey T. Constructing the Olympic Dream: A Future Perfect Strategy of Project Management. Organization Science 2003; 14: $574-590$

[48] Winch, G. M. Bonke, S. Project stakeholder mapping: analyzing the interests of project stakeholders. In: In: Slevin D. P., Cleland D. I., Pinto J. K. (eds.), The Frontiers of Project Management Research, Project Management Institute, PMI, USA, 2002.

[49] Engwall, M. No project is an island: linking projects to history and context. Research Policy 2003, 32:789-808

[50] Slevin D. P., Pinto J. K. Balancing Strategy and Tactics in Project Implementation Sloan Management Review 1987; 29(1): 33-41

[51] Parsons, T. Structure and process in modern societies. Glencoe: Free Press, 1960. 
[52] Lampel, J., Jha P. P. Models of project orientation in multiproject organizations. (pp. 223-236) In: Morris P. W. G. and Pinto J. K. (eds.). The Wiley Guide to Managing Projects, 223-236. London: John Wiley \& Sons Inc, 2004.

[53] Burgelman, R. A. A model of the interaction of strategic behavior, corporate context, and the concept of strategy. Academy of Management Review 1983; 8: 61-70

[54] Burgelman, R. A. A process model of internal corporate venturing in the diversified major firm. Administrative Science Quarterly1983; 28: 223-244

[55] Burgelman, R. A. Corporate entrepreneurship and strategic management: Insights from a process study. Management Science1983; 29: 1349-1364

[56] Burgelman, R. A. Intraorganizational ecology of strategy making and organizational adaptation: Theory and field research. Organizational Science 1991, 2: 239-262

[57] Burgelman, R. A. A process model of strategic business exit: Implications for an evolutionary perspective on strategy. Strategic Management Journal 1996; 17: 193-214

[58] Hart, S. An integrative framework for strategy-making process. Academy of Management Review 1992; 17: 327-351

[59] Hart, S., Banbury, C. How strategy-making processes can make a difference. Strategic Management Journal 1994; 15: 251-269

[60] Mintzberg, H. Patterns in strategy formation. Management Science1978; 24: 934-948

[61] Fredrickson, J. W., Mitchell, T. R. Strategic decision processes: comprehensiveness and performance in an industry with an unstable environment. The Academy of Management Journal 1984; 22: 399-423

[62] Mintzberg, H. \& Waters, J. A. Of strategies, deliberate and emergent. Strategic Management Journal 1985; 6: 257-272

[63] Nonaka, I. Toward middle-up-down management: Accelerating information creation. Sloan Management Review 1988; Spring: 9-18

[64] Porter, M. E. Competitive strategy: Techniques for analyzing industries and competitors. New York: Free Press, 1980. 
Table 1. Summary of literature on the concept of project strategy

\begin{tabular}{ll}
\hline $\begin{array}{l}\text { Literature track } \\
\text { Examples of sources }\end{array}$ & $\begin{array}{l}\text { Main contribution to project strategy concept } \\
\text { and potential research gaps }\end{array}$ \\
$\begin{array}{l}\text { project strategy } \\
\text { viewpoint }\end{array}$ &
\end{tabular}

Project as $\quad[10,11,7,12,6,13,14$,
subordinate to a $\quad 15,8,4,5,16]$
parent
organization

This literature concentrates on project strategy formulation through a top-down process starting from the parent organization's business strategy. As this strategy formulation process is fixed, the project is not allowed to form its strategy independently, but the project's strategy is an image of the parent organization's strategy and the project is in a role of implementing its parent's strategy. Project strategy is a static plan (or predetermined management approaches like guidelines or attitude/perspective given to the project) that is formulated in the front end stage of the project. The elements of project strategy are explained either through their inclusion into specific standard project management processes, or through copying/translating component parts of the firm's strategy to the project, such as e.g. positioning of the firm's product in the external competitive market landscape, or competitive advantage in this external marketplace. This literature concentrates on the parent's and its project's activities in parent's external environment, and parent organization's internal environment is not considered as the external environment for the project that would affect the project's strategy. 
Project as an

autonomous

organization but

connected to a

parent

organization
[27, 23, 22, 24, 28, 26, 9, This literature has two distinct conceptions of 25] project strategy. First, a project carries within its boundaries significant responsibility for the business that it is expected to establish, and accordingly, the project is authorized and resourced to choose and implement its directions independently. Second, the project's strategy is seen as project execution strategy, where the project's authority is limited to independent strategies in project execution and in project management, but not in the actual overall business content/result that the project is expected to implement.

Project in a $[31,34,50,35,46,36$, This literature sees the project as an complex environment $37,38,39,40,44,47,45$ 41]

with unclear

overall

governance

scheme organization/entity that is positioned in a complex organizational environment with several powerful stakeholders, and not just one powerful parent organization. Project strategy of such project relates to the project's adaptation to its environment. This literature assumes that project strategy is self-originated and it is related to the project's own governance structure; the project includes within its boundaries all management levels of any successful and independent enterprise (institutional/strategic, middle management, technical-tactical levels). 
Figure 1. Four obvious project strategies depending on project's independence and number of strong project stakeholder organizations

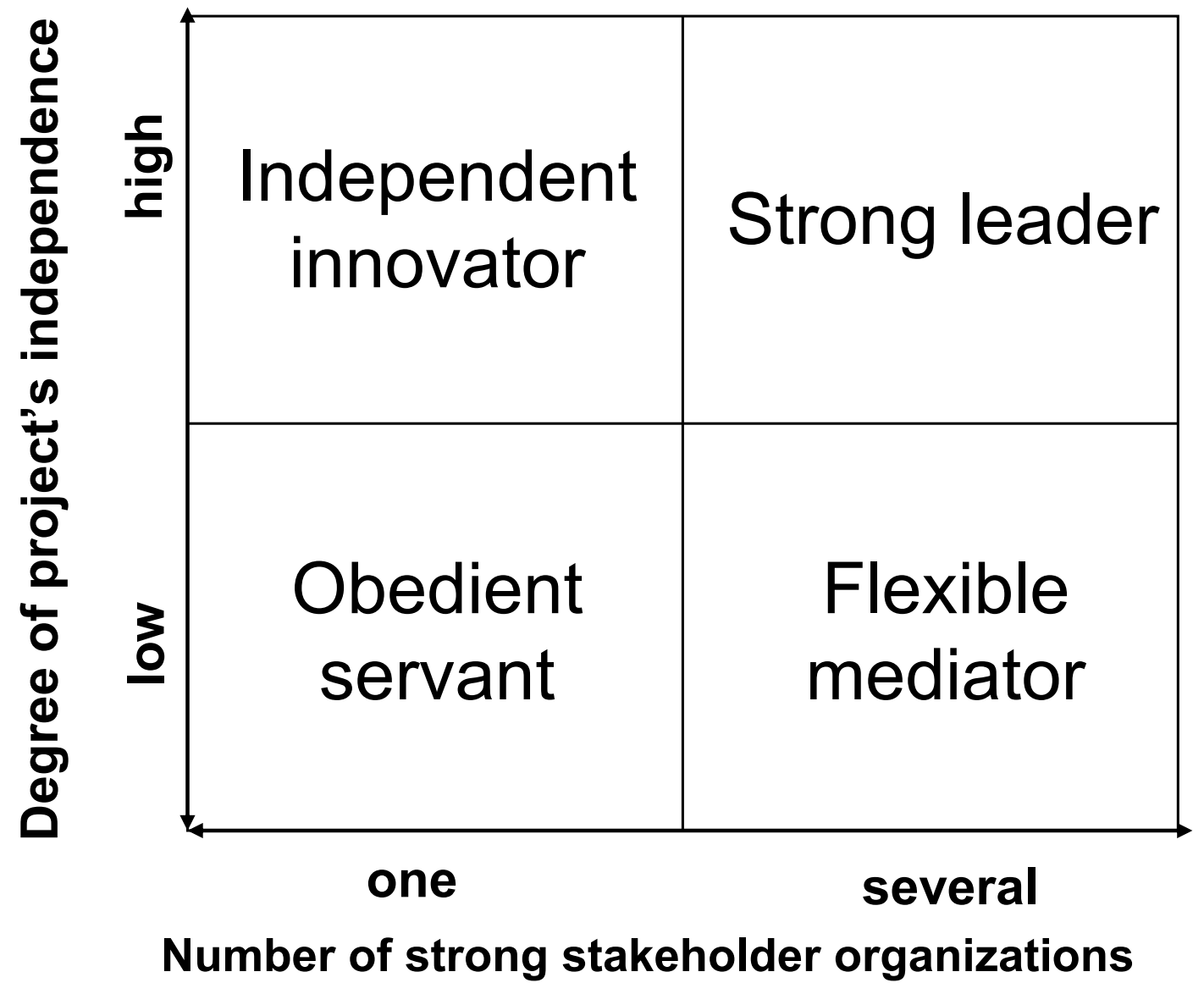

